\title{
APAKAH EARNINGS MANAGEMENT MAMPU MENGURANGI TINGKAT STICKINESS COST?
}

\section{Rani Media Martania*), Nurafni Eltivia, Mohamad Arief Setiawan}

Politeknik Negeri Malang, Jl. Soekarno Hatta No.09, Malang, Jawa Timur, Indonesia. Email Koresponden : ranimartania96@gmail.com

\section{Abstract}

The purpose of this research is to determine the occurence of stickiness cost in SG\&A (Selling, General and Administration) cost and to see whether the stickiness cost degree can be derive through earning management. Multiple linear regression using regression model from Anderson et al. and Farzaneh et al. are carried out to analyze the data. The results of this research show that SG\&A cost is sticky, because it increased by $0.908 \%$ at $1 \%$ increase in sales but decreased by $0.016 \%$ at $1 \%$ decrease in sales. It happens because the manager retain the unutilized resources when facing a decline in sales. Furthemore, the results of this research find that earning management can derive the degree of stickiness cost, even cause anti-sticky in SG\&A cost. It happens because the manager who has an incentive to avoid reporting loses and earning decreases, try to reduce cost when sales decline by earning management.

Keywords: Discretionary Accrual, Earning Management, Selling, General and Administration Cost, Stickiness Cost.

\section{PENDAHULUAN}

Ketatnya persaingan dalam dunia bisnis menimbulkan adanya fluktuasi tingkat permintaan produk yang tidak mudah diprediksi. Oleh sebab itu, pemahaman manajer terhadap perilaku biaya merupakan hal yang sangat penting untuk membantu memenangkan persaingan. Susilo (2016) menyatakan bahwa manajer yang memahami perilaku biaya lebih baik dalam memprediksi apa yang akan terjadi pada alur biaya dibeberapa situasi operasi, serta memudahkan untuk perencanaan aktivitas.

Perilaku biaya didefinisikan sebagai kecenderungan perubahan biaya untuk merespon perubahan volume aktivitas (Samryn, 2012, p. 46). Berdasarkan perilaku biaya tradisional, perubahan biaya bergerak secara proporsional terhadap volume aktivitas perusahaan. Namun, berdasarkan hasil penelitian yang dilakukan Anderson, Banker \& Janakiraman (2003) menunjukkan bahwa biaya bergerak secara tidak proporsional terhadap perubahan volume aktivitas. Bahkan hasil penelitian tersebut juga sejalan dengan penelitian yang telah dilakukan di beberapa negara seperti Brazil (Medeiros \& Costa, 2004), Iran (Farzaneh, Javad, Mahdi $\&$ Haddad, 2013), Amerika Utara (Zhang, 2016) dan Indonesia (Eltivia, Widiastuti \& Wahyuni., 2017). Pergerakan biaya dikatakan tidak proporsional karena, jumlah peningkatan biaya yang disebabkan kenaikan volume aktivitas lebih besar daripada jumlah penurunan biaya yang disebabkan penurunan volume aktivitas, dan kondisi tersebut dikenal dengan istilah stickiness cost.

Xue \& Hong (2016) menyatakan bahwa terdapat dua sudut pandang yang digunakan untuk melihat keberdaan stcikiness cost, yaitu rational decision-making dan motivational. Sudut pandang yang pertama menganggap stickiness cost sebagai hasil dari keputusan manajer setelah mempertimbangkan biaya dan

125

Diterima:

03 September 2018

Direvisi:

11 Oktober 2018

Disetujui:

23 Oktober 2018

Artikel ini tersedia di website: http:// ejournal.umm.ac.id/ index.php/jrak

Doi: 10.22219/ jrak.v8i2.32

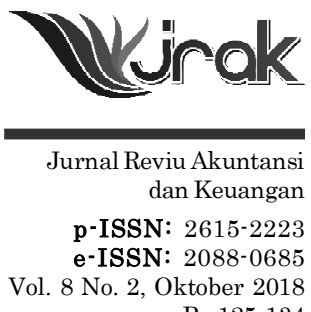

Pp 125-134 
Apakah Earnings Management... manfaat setiap alternatif pilihan. Anderson et al. (2003) menyatakan bahwa ketika manajer menghadapi ketidakpastian tingkat penjualan di masa depan dan perusahaan harus menanggung biaya penyesuaian atas penyesuaian sumber daya, maka manajer akan menunda untuk mengurangi sumber daya sampai mereka meyakini sifat dari penurunan penjualan adalah permanen. Hal ini dilakukan karena setiap penyesuaian, baik menambah atau mengurangi sumber daya akan menimbulkan adanya biaya penyesuaian yang jumlahnya lebih mahal ketika terjadi penurunan permintaan (Windyastuti, 2013).

Pada sudut pandang yang kedua, stickiness cost dianggap sebagai hasil dari intervensi manajer yang memiliki insentif manajerial tertentu dalam mengelola operasional perusahaan. Chen, Lu \& Sougiannis (2008) menyatakan apabila pemegang saham sulit mengawasi perilaku manajer, maka manajer akan mempertahankan sumber daya menganggur ketika penjualan menurun untuk meningkatkan utilitas pribadi melalui status, kekuasaan, kompensasi dan gengsi. Sebagaimana yang telah dinyatakan oleh Chen et al. (2008) bahwamanajer akan memiliki gengsi yang semakin tinggi apabila sumber daya yang berada di bawah pengawasannya meningkat. Sementara, Anderson et al. (2003) menyebutkan bahwa status manajer akan menurun apabila divisinya mengalami pengurangan karyawan.

Weiss (2009) menyatakan bahwa pada perusahaan yang memiliki tingkat stickiness cost tinggi, menunjukkan penurunan laba yang semakin besar ketika penjualan menurun. Hal ini terjadi karena kecilnya penyesuaian biaya yang dapat dilakukan perusahaan ketika penjualan menurun, sehingga menurunkan jumlah laba yang dihasilkan perusahaan. Selain itu, berdasarkan penelitian juga menunjukkan bahwa stickiness cost dapat menurunkan tingkat akurasi peramalan laba perusahaan (Weiss, 2009; Susilo, 2016). Padahal, peramalan laba merupakan dasar bagi manajemen dan investor untuk mengambil keputusan-keputusan ekonomi.

Berdasarkan penelitian terdahulu milik Koo, Seungah \& Paik (2014), Xue \& Hong (2016), Hemati \& Javid (2017), serta Jin (2017), tingkat stickiness cost akan berkurang apabila suatu perusahaan melakukan praktik upwardearning management, yaitu tindakan meningkatkan laba diatas laba yang sesungguhnya. Apabila dihubungkan dengan agency theory, alasan manajer melakukanpraktik tersebut dapat dijelaskan melalui sudut pandang oportunistik. Adanya pemisahan kepemilikan dan pengelolaan perusahaan menimbulkan dua permasalahan, yakni konflik kepentingan dan asimetri informasi. Konflik kepentingan timbul karena kedua pihak ingin memaksimalkan kesejahteraannya masing-masing. Semakin tinggi konflik tersebut, maka dapat dipastikan bahwa manajer akan berupaya untuk menyalahgunakan wewenang dan mengabaikan kepentingan pemilik. Hal ini terjadi karena manajer mendapat bantuan dari masalah lain yang timbul akibat pemisahaan kepemilikan dan pengelolaan, yaitu asimetri informasi. Manajer sebagai pengelola perusahaan akan memiliki lebih banyak informasi internal daripada pemilik. Semakin tinggi tingkat asimetri informasi, maka semakin leluasa manajer untuk mengatur informasi apa saja yang perlu diungkapkan, disembunyikan, ditunda atau diubah (Sulistyanto, 2008, $p$. 85). Dengan demikian, kedua permasalahan tersebut dapat memberikan dorongan sekaligus kesempatan pada manajer untuk berperilaku oportunis guna memenuhi kepentingan pribadinya.

Xue \& Hong (2016), serta Hemati \& Javid (2017) menyatakan bahwa motivasi dari manajer yang mendorong praktik upward earning management adalah insentif untuk menghindari melaporkan kerugian dan penurunan laba. Metode yang dapat digunakan untuk mewujudkan praktik tersebut adalah menggeser periode pengakuan biaya dan pendapatan atau mengubah estimasi dan metode akuntansi, sehingga biaya periode berjalan menjadi lebih kecil. Selain itu, manajemen dapat memanfaatkan komponen akrual untuk dimanipulasi. Hal ini dikarenakan, transaksi akrual tidak memerlukan bukti kas secara fisik, sehingga manajemen dapat leluasa untuk mengatur besar kecilnya angka transaksi yang dimanipulasi (Sulistyanto, 2008, p. 163). 
Penelitian mengenai stickiness cost sudah banyak dilakukan di berbagai negara. Namun, penelitian yang menghubungkan stickiness cost dengan erning management masih jarang ditemukan. Beberapa penelitian terdahulu antara lain, Koo Seungah \& Paik (2014) yang meneliti perusahaan-perusahaan di Amerika Serikat serta Jin (2017) yang meneliti perusahaan-perusahaan di China menemukan bahwa earning management terbukti mampu mengurangi tingkat stickiness cost pada perusahaan-perusahaan di kedua negara tersebut. Selanjutnya, Xue \& Hong (2016) yang meneliti perusahaan-perusahaan di China serta Hemati \& Javid (2017) yang meneliti perusahaan di Iran juga menemukan hasil yang sama. Lebih jauh lagi, mereka menguji tingkat efisiensi dari penurunan stickiness cost dan menemukan bahwa penurunan tersebut sudah dilakukan secara efisien dengan mengurangi pengeluaran biaya umum lainnya. Sementara di Indonesia, penelitian yang sejenis dengan penelitian ini belum banyak dilakukan di Indonesia. Beberapa penelitian terdahulu hanya ditujukan untuk mengetahui apakah stickiness cost terjadi pada perusahaan manufaktur di Indonesia (Apriliawati \& Nugrahanti, 2015; Eltivia et al.,2017; Vonna \& Daud, 2016).

Penelitian ini bertujuan untuk menguji keberadaan stickiness cost pada perusahaan manufaktur di Indonesia, serta untuk mengetahui apakah earning management mampu mengurangi tingkat stickiness cost. Perbedaan dengan penelitian terdahulu terletak pada obyek penelitian yang digunakan, serta model persamaan regresi yang digunakan untuk menguji kemampuan earning management untuk mengurangi tingkat stickiness cost. Obyek yang digunakan pada penelitian terdahulu adalah perusahaan-perusahaan di Amerika, China dan Iran, sedangkan penelitian ini menggunakan perusahaan manufaktur di Indonesia. Selain itu, model persamaan regresi dari keempat penelitian terdahulu merupakan hasil modifikasinya sendiri, sedangkan penelitian ini menggunakan hasil modifikasi dari Farzaneh et al. (2013).

\section{Hipotesis}

\section{Keberadaan Stickiness Cost di Perusahaan Manufaktur Indonesia}

Berdasarkan penelitian milik Apriliawati \& Nugrahanti(2015), Eltivia et al. (2017),serta Vonna \&Daud(2016) menunjukkan bahwa perusahaan manufaktur di Indonesia mengalami stickiness cost.Kondisi ini terjadi karena adanya intervensi manajer dalam proses penyesuaian sumber daya terhadap tingkat penjualan. Manajer memilih untuk mempertahankan sejumlah sumber daya menganggur ketika terjadi penurunan penjualan. Dengan demikian, biaya tidak akan mengalami banyak penurunan ketika penjualan menurun dan menimbulkan stickiness cost. Berdasarkan penjelasan tersebut, maka dapat dirumuskan hipotesis sebagai berikut:

$\mathrm{H}_{1}$ : Biaya PA\&U pada perusahaan manufaktur yang terdaftar di BEI pada tahun 2015 - 2016 bersifat sticky.

\section{Kemampuan Earning Management dalam Mengurangi Tingkat Sticki- ness Cost}

Penelitian yang dilakukan oleh Koo, Seungah \& Paik (2014), Xue \& Hong (2016), Hemati \& Javid (2017), serta Jin (2017) menunjukkan bahwa earning management, khususnya pola upward earning management,dapat mengurangi tingkat stickiness cost pada perusahaan di Amerika Serikat, China dan Iran.Ketika manajer menghadapi insentif untuk menghindari melaporkan kerugian atau penurunan laba, maka mereka akan mengurangi biaya periode berjalan melalui praktik upward earning management. Dengan demikian, biaya akan menurun seiring dengan penurunan penjualan, sehingga tingkat stickiness cost pun dapat berkurang. Berdasarkan penjelasan tersebut, maka dapat dirumuskan hipotesis sebagai berikut: 
Apakah Earnings

Management...

Tabel 1. Proses Pengambilan Sampel
$\mathrm{H}_{2}$ : Upward earning management dapat mengurangi tingkat stickiness cost perusahaan manufaktur yang terdaftar di BEI pada tahun 2015 - 2016.

\section{METODE PENELITIAN}

Pendekatan dari penelitian ini adalah kuantitatif. Penelitian ini merupakan penelitian asosiatif yang menguji apakah earning management berpengaruh terhadap stickiness cost. Populasi dari penelitian ini adalah perusahaan manufaktur yang terdaftar di BEI tahun 2015 - 2016 dan berjumlah sebanyak 288 data. Sampel penelitian diambil menggunakan teknik purposive sampling, dimana pemilihan sampel didasarkan pada kriteria - kriteria tertentu. Adapun proses penyeleksian sampel disajikan dalam tabel 1.

\section{Keterangan}

Jumlah

Perusahaan manufaktur yang secara konsisten terdaftar di Bursa

Efek Indonesia selama periode 2015 - 2016

Perusahaan manufaktur yang belum melakukan IPO sebelum 1 Januari 2015

Perusahaan manufaktur yang tidak secara konsisten menerbitkan laporan keuangan selama periode tahun 2015 - 2016

Perusahaan manufaktur yang tidak memiliki data-data yang dibutuhkan dalam penelitian ini

Jumlah sampel hipotesis 1
Perusahaan manufaktur yang melaporkan rugi pada periode $2015-$
2016
Perusahaan manufaktur yang pada tahun $2015-2016$ tidak
melakukan praktik upward earning management

Jumlah sampel hipotesis 2

Penelitian ini menggunakan data sekunder berupa laporan keuangan serta nilai kurs rupiah yang diperoleh dari website www.idx.co.id dan www.bi.go.id.Variabel dependen dalam penelitian ini adalah biaya PA\&Usebagai proksi dari stickiness cost. Biaya PA\&U diperoleh dari laporan keuangan, kemudian nilai biaya PA\&U periode $\mathrm{t}$ dibandingkan dengan periode $\mathrm{t}-1$ dengan rumus berikut:

$$
\frac{\mathrm{PA} \& U_{\mathrm{i}, \mathrm{t}}}{\mathrm{PA} \& U_{\mathrm{i}, \mathrm{t}-1}}
$$

Sementara variabel independen dalam penelitian ini antara lain, penjualan bersih, dummy penjualan bersih dan discretionary accrual. Variabel penjualan bersih merupakan total penjualan setelah dikurangi dengan faktor-faktor pengurang seperti harga pokok penjualan, retur, diskon dan komisi penjualan. Penjualan bersih digunakan sebagai proksi dari volume penjualan, dan nilainya diperoleh dari laporan keuangan. Kemudian, nilai penjualan bersih periode $t$ dibandingkan dengan periode t-1 sebagaimana rumus berikut:

Variabel dummy penjualan bersih merupakan variabel yang mengalikan antara nilaidummy dan perbandingan penjualan bersih periode $\mathrm{t}$ dengan $\mathrm{t}-1$. Berikut adalahrumusdari variabel tersebut:

$$
\frac{\mathrm{PB}_{\mathrm{i}, \mathrm{t}}}{\mathrm{PB}_{\mathrm{i}, \mathrm{t}-1}}
$$


Nilai dummy merepresentasikan peningkatan dan penurunan penjualan bersih antara periode $\mathrm{t}$ dan $\mathrm{t}-1$. Apabila penjualan bersih meningkat, maka dummy akan bernilai 0, apabila sebaliknya akan bernilai 1 . Selanjutnya, variabel discretionary accrual merupakan perkalian dari nilai dummy, perbandingan penjualan bersih periode $t$ dengan $\mathrm{t}-1$, dan nilai discretionary accrual (DA). Berikut adalah rumus dari variabel tersebut:

Dummy penjualan bersih $=$

$$
\text { Dummy }_{i, t} * \frac{\mathrm{PB}_{\mathrm{i}, \mathrm{t}}}{\mathrm{PB}_{\mathrm{i}, \mathrm{t}-1}}
$$

Penjelasan mengenai nilai dummy dan perbandingan penjualan bersih periode t dengan t-1 sama seperti yang telah dikemukakan sebelumnya. Sementara, nilai DA merupakan proksi dari earning management yang didapat melalui perhitungan berdasarkan modified jones model. Pemilihan metode tersebut didasarkan pada beberapa hasil penelitian yang mengatakan bahwa modified jones model merupakan model yang paling baik di antara model-model akrual agregat yang lain (Miko \& Kamardin, 2014; Bešliæ, I., Bešliæ, D., Jakšiæ, \& Andriæ, 2015; Suyono, 2017; Abdurrahim, 2015).

Alat analisis dalam penelitian ini menggunakan regresi linier berganda. Prosedur analisis dimulai dengan melakukan uji asumsi klasik, dan selanjutnya menguji hipotesis satu dan dua. Terdapat dua model persamaan regresi dalam penelitian ini. Untuk menguji keberadaan stickiness cost pada perusahaan manufaktur di BEI tahun 2015 - 2016, menggunakan model persamaan regresi milik Anderson et al. (2003) :

$$
\log \left[\frac{\mathrm{PA} \& U_{i, \mathrm{t}}}{{\mathrm{PA} \& U_{i, t-1}}_{i}}\right]=\beta_{0}+\beta_{1} \log \left[\frac{\mathrm{PB}_{i, \mathrm{t}}}{\mathrm{PB}_{\mathrm{i}, \mathrm{t}-1}}\right]+\beta_{2} \text { Dummy }^{*} \log \left[\frac{\mathrm{PB}_{\mathrm{i}, \mathrm{t}}}{\mathrm{PB}_{\mathrm{i}, \mathrm{t}-1}}\right]+\varepsilon_{\mathrm{i}, \mathrm{t}}
$$

Dummy akan bernilai 0 ketika penjualan bersih meningkat, sehingga nilai koefisien $\beta_{1}$ menunjukkan persentase kenaikan biaya PA\&U setiap 1\% kenaikan penjualan bersih. Sebaliknya, nilai dummy akan berubah menjadi 1 ketika penjualan bersih mengalami penurunan, sehingga penjumlahan koefisien $\beta_{1}$ dan $\beta_{2}$ menunjukkan persentase penurunan biaya setiap 1\% penurunan penjualan bersih. Apabila biaya PA\&U bersifat sticky,maka persentase kenaikannya harus lebih besar dari persentase penurunan. Dengan demikian, $H_{1}$ diterima apabila $\beta_{1}>0$ dan $\beta_{2}<$ 0 .

Sementara, untuk menguji kemampuanearning management dalam mengurangi tingkatstickiness cost pada perusahaan manufaktur di BEI tahun 2015 - 2016,model persamaan yang digunakan adalah milik Farzaneh et al. (2013):

$\log \left[\frac{\mathrm{PA} \& U_{\mathrm{i}, \mathrm{t}}}{\mathrm{PA} \& U_{\mathrm{i}, \mathrm{t}-1}}\right]=\beta_{0}+\beta_{1} \log \left[\frac{\mathrm{PB}_{\mathrm{i}, \mathrm{t}}}{\mathrm{PB}_{\mathrm{i}, \mathrm{t}-1}}\right]+\beta_{2}$ Dummy $\log \left[\frac{\mathrm{PB}_{\mathrm{i}, \mathrm{t}}}{\mathrm{PB}_{\mathrm{i}, \mathrm{t}-1}}\right]+\beta_{3}$ Dummy $\log \left[\frac{\mathrm{PB}_{\mathrm{i}, \mathrm{t}}}{\mathrm{PB}_{\mathrm{i}, \mathrm{t}-1}}\right] \mathrm{DA}+\varepsilon_{i, t}$

\section{Keterangan:}

PA\&U : Biaya penjualan, administrasi danUmum

PB : Penjualan bersih

Dummy : Dummy dari penjualan bersih,bernilai 0 apabila meningkat, dan 1 apabila menurun

DA

:Discretionary accrual 
Apakah Earnings Management...

130
Oleh karena nilai dummy adalah 0 ketika penjualan bersih meningkat, maka nilai koefisien $\beta_{1}$ menunjukkan persentase kenaikan biaya PA\&U setiap $1 \%$ kenaikan penjualan bersih. Sebaliknya, nilai dummy akan berubah menjadi 1 ketika penjualan bersih mengalami penurunan, sehingga penjumlahan koefisien $\beta_{1} \beta_{2}$ dan $\beta_{3}$ menunjukkan persentase penurunan biaya yang dipengaruhi oleh variabel upward earning management (diproksikan oleh discretionary accrual) disetiap 1\% penurunan penjualan bersih. Apabila upward earning management dapat menurunkan tingkat stickiness cost pada biaya PA\&U, maka tanda pada koefisien $\beta_{2}$ harus negatif dan koefisien $\beta_{3}$ harus positif. Dengan demikian, $\mathrm{H}_{2}$ diterima apabila $\beta_{1}$ dan $\beta_{3}>0$ dan $\beta_{2}<0$.

\section{HASIL DAN PEMBAHASAN}

Pertama-tama, penelitian ini melakukan uji asumsi klasik yang terdiri dari uji normalitas, multikolinieritas, heteroskedastisitas dan autokorelasi sebelum menguji kedua hipotesis. Kemudian, berdasarkan hasil pengujian menunjukkan bahwa kedua model persamaan regresi telah lolos uji asumsi klasik. Selanjutnya, penelitian ini menggunakan model persamaan regresi dari Anderson et al. (2003) untuk menguji hipotesis satu. Adapun hasil pengujiannya disajikan pada tabel 2.

Berdasarkan tabel 2 , terlihat bahwa nilai koefisien $\beta_{1}>0$ yaitu sebesar 0,908 dan nilai koefisien $\beta_{2}<0$ yaitu sebesar $-0,892$. Selanjutnya, dapat diketahui bahwa setiap 1\% kenaikan penjualan bersih akan meningkatkan biaya PA\&U sebesar $0,908 \%$, sedangkan setiap $1 \%$ penurunan penjualan bersih akan menurunkan biaya PA\&U sebesar $(0,908-0,892) \quad 0,016 \%$. Dengan demikian, dapat ditarik kesimpulan bahwa biaya PA\&U pada perusahaan manufaktur yang terdaftar di BEI tahun 2015 - 2016 memiliki sifat sticky.

\section{Coefficients $^{\mathrm{a}}$}

\begin{tabular}{lcc}
\hline & \multicolumn{2}{c}{ Unstandardized Coefficients } \\
\cline { 2 - 3 } & $\mathrm{B}$ & Std. Error \\
\hline (Constant) & .009 & .004 \\
Penjualan bersih & .908 & .118 \\
Dummy penjualan bersih & .892 & .161 \\
\hline
\end{tabular}

Stickiness cost terjadi karena adanya intervensi dari manajer dalam menyesuaikan tingkat sumber daya untuk merespon perubahan penjualan (Anderson et al., 2003). Efek samping dari penyesuaian sumber daya adalah timbulnya biaya penyesuaian yang jumlahnya lebih besar ketika penjualan menurun dibandingkan ketika penjualan meningkat. Oleh sebab itulah, manajer perlu melakukan evaluasi terhadap sifat dari penurunan tersebut. Apabila manajer masih ragu bahwa penurunan penjualan bersifat tetap, maka mereka cenderung mempertahankan sumber daya yang menganggur, ketika menghadapi penurunan penjualan. Pada akhirnya, tindakan tersebut menyebabkan jumlah biaya tidak banyakberkurang, sehingga terjadilah stickiness cost.

Selain itu, stickiness cost juga terjadiakibat manajer mempertahankan sumber daya menganggur ketika penjualan menurun, untuk meningkatkan utilitas pribadi manajer. Ketika penjualan menurun, maka manajer enggan mengurangi sumber daya yang ada dibawah pengawasannya. Dengan demikian, kondisi tersebut menyebabkan terjadinya stickiness cost.Hasil penelitian ini sejalan dengan penelitian terdahulu milik Apriliawati \& Nugrahanti (2015), Vonna \& Daud (2016), serta Eltivia, Widiastuti \& Wahyuni (2017).

Selanjutnya, hipotesis dua diuji dengan menggunakan model persamaan regresi dari Farzaneh et al. (2013). Adapun hasil pengujiannya ditunjukkan pada tabel 3. 


\begin{tabular}{lcc}
\hline & \multicolumn{2}{c}{ Unstandardized Coefficients } \\
\cline { 2 - 3 } & $\mathrm{B}$ & Std. Error \\
\hline (Constant) & .016 & .007 \\
Penjualan bersih & .594 & .132 \\
Dummy penjualan bersih & -.599 & .240 \\
Discretionary accrual & 2.107 & 2.058 \\
\hline
\end{tabular}

Berdasarkan tabel 3 dapat disimpulkan bahwa upward earning management dapat menurunkan tingkat stickiness cost, karenanilai koefisien $\beta_{1}>0$ yaitu 0,594, nilai koefisien $\beta_{2}<0$ yaitu $-0,599$, dan nilai koefisien $\beta_{3}>0$ yaitu 2,107 . Sementara, setiap 1\% kenaikan penjualan bersih akan meningkatkan biaya PA\&U sebesar $0,594 \%$, dan adanya praktik upward earning management akan menurunkan biaya PA\&U sebesar $2,102 \%$ pada $1 \%$ penurunan penjualan bersih. Oleh karena besarnya persentase kenaikan biaya $(0,594 \%)$ lebih kecil daripada persentase penurunan biaya $(2,102 \%)$, maka biaya PA\&U tidak lagi mengalami stickiness cost melainkan berubah menjadi anti-sticky. Anti-sticky adalah kondisi dimana persentase peningkatan biaya akibat meningkatnya penjualan lebih kecil daripada penurunan biaya akibat penurunan penjualan (Weiss, 2009). Dengan demikian, dapat disimpulkan bahwa praktik upward earning management mampu menurunkan tingkat stickiness cost, bahkan dapat menyebabkan anti-sticky pada biaya PA\&U.

Agency theory mengatakan bahwa pemisahan antara kepemilikan dan pengelolaan perusahaan menyebabkan timbulnya masalah keagenan. Pemilik dan manajemen sama-sama mementingkan diri sendiri sehingga menimbulkan konflik kepentingan. Selain itu, pihak manajemen sebagai pengelola operasional perusahaan mengetahui lebih banyak informasi internal dibandingkan pemilik, sehingga menimbulkan adanya asimetri informasi. Pada akhirnya, kedua masalah tersebut memberikan kesempatan manajer untuk melakukan earning management.

Apabila manajer memiliki insentif untuk menghindari melaporkan kerugian dan penurunan laba, maka mereka akan mengurangi biaya ketika penjualan menurun. Pengurangan tersebut dilakukan melalui praktik upward earning management. Manajer dapat membuat laba lebih besar dari sesungguhnya dengan memilih metode penyusutan jumlah angka tahun, memperpanjang estimasi umur ekonomis dan memperbesar nilai residu aktiva tetap. Pemilihan metode dan prosedur penyusutan aktiva tetap tersebut dapat menghasilkan biaya yang relatif lebih kecil, sehingga akan menghasilkan jumlah laba yang lebih besar.

Selain itu, manajemen dapat memanfaatkan komponen akrual untuk dimanipulasi. Contohnya dengan memperpanjang estimasi masa pengalokasian biaya dibayar dimuka, atau memperlambat pengakuan biaya, sehingga menghasilkan biaya lebih kecil yang pada akhirnya memperbesar laba. Dengan demikian, manajer dapat mengurangi jumlah biaya ketika mengalami penurunan penjualan melalui praktik upward earning management, sehingga penurunan biaya menjadi lebih besar dan tingkat stickiness cost pun dapat diturunkan. Namun, apabila manajer mengurangi biaya yang terlalu banyak demi mencapai target laba, maka akan terjadi anti--sticky karena penurunan biaya lebih besar daripada kenaikan biaya.Hasil penelitian ini sejalan dengan penelitian milik Koo, Seungah \& Paik (2014), Xue \& Hong (2016), Hemati \& Javid (2017) serta Jin (2017).

\section{SIMPULAN}

Hasil penelitian menunjukkan bahwa perusahaan manufaktur yang terdaftar di BEI tahun 2015 - 2016 bersifat sticky. Jumlah kenaikan biaya PA\&U ketika 
penjualan bersih meningkat lebih besar daripada penurunan biaya PA\&U ketika penjualan bersih menurun. Penyebanya adalah adanya kecenderungan manajer untuk mempertahankan sumber daya menganggur ketika penjualan bersih menurun.

Selain itu, hasil penelitian juga menunjukkan bahwa praktik upward earning management dapat menurunkan tingkat stickiness cost, bahkan dapat menimbulkan anti-sticky pada biaya PA\&U. Hal ini terjadi karena manajer yang memiliki insentif untuk menghindari melaporkan kerugian dan penurunan laba, akan berusaha mengurangi sejumlah biaya ketika penjualan menurun. Salah satunya, dilakukan dengan cara meningkatkan laba diatas laba sebenarnya melalui praktik upward earning management.

Penelitian ini hanya menggunakan salah satu pola earning management untuk menguji pengaruhnya terhadap stickiness cost. Selain itu, penelitian ini tidak melakukan pengujian lebih jauh untuk melihat apakah penurunan stickiness cost sudah efisien atau belum. Oleh karena itu, diharapkan pada penelitian selanjutnya pengujian efisiensi penurunan tersebut dapat dilakukan. Dalam penelitian ini, sudut pandang yang digunakan untuk melihat earning management adalah oportunistik, diharapkan penelitian selanjutnya dapat meninjau dari sudut pandang lain, misalnya perspektif informasional.

\section{DAFTAR PUSTAKA}

Abdurrahim, A. 2015. Mendeteksi Earning Management. Jurnal Akuntansi \& Investasi. Vol. 1, No. 2.

Anderson, M., R. Banker, \& S. Janakiraman. (2003). "Are Selling, General, and Administrative Costs 'Sticky'?'. J. Acc. Res. Vol. 41.

Apriliawati, R. \& Y., W., Nugrahanti. 2015. Perilaku Sticky Cost Pada Biaya Penjualan, Administrasi dan Umum (Studi Pada Perusahaan Manufaktur yang Terdaftar di Bursa Efek Indonesia Periode 2009 - 2012).Jurnal Ekonomi \&Pembangunan. Vol.5, No. 2.

Bešliæ, I., D., Bešliæ, D., Jakšiæ \& M., Andriæ. 2015. Testing the Models for Detection of Earnings Management. Industrija. Vol. 43, No. 3.

Chen, C., X., H., Lu \& T., Sougiannis. 2008. Managerial Empire Building, Corporate Governance, and the Asymmetrical Behavior of Selling, General, and Administrative Costs. Contemporary Accounting Research.Vol. 29, No. 1.

Eltivia, N., R., Widiastuti \& H., Wahyuni. 2017. Do Stickiness Costs Exist in Indonesia. Review of Integrative Business \& Economics Research. Vol 6, No. 1.

Farzaneh N., S.M., Javad, S., Mahdi \& B.S.A., Haddad. 2013. A Study of The Stickiness of Cost of Goods Sold and Operating Cost to Changes in Sales Level in Iran. Studies inBusiness and Economic. Vol. 8, No. 2.

Hemati, M. \& D., Javid. 2017. The Effect of the Earning Management and Corporate Governance on Expense Stickiness. International Journal of Accounting Research. Vol. 5, No. 2.

Jin, Y. 2017. Does Earning Management Affect the Cost Stickiness of Corporate?. Advances in Computer Science Research (ACSR). Vol. 61.

Koo, J. H., S., Seugah. \& T. Y., Paik. 2015. Earning Management and Cost Stickiness. Advanced Science and Technology Letters. Vol. 84.

Medeiros, O.R. \& P.S., Costa. 2004. "Cost Stickiness in Brazilian Firms". Available online at https://papers.ssrn.com (Diakses pada 2 Juni 2018)

Miko, N., U. \& H., Kamardin. 2014. Detecting Earnings Management : Comparative Analysis Of Models In Nigeria. Journal of Accounting Frontier. Vol. 16, No.2. 
Samryn, L.M. (2012). Akuntansi Manajemen : Informasi Biaya untuk Mengendalikan Aktivitas Operasi \& Investasi. Jakarta : Kencana.

Sulistyanto, S., H. 2008. Manajemen Laba : Teori dan Model Empiris. Jakarta : Grasindo

Susilo, E. 2016. Analisis Perilaku Sticky Cost dan Pengaruhnya Terhadap Prediksi Laba Menggunakan Model Cost Variability dan Cost Stickiness (CVCS) Pasda Emiten di BEI Untuk Industri Manufaktur. Akademi Akuntansi Keuangan dan Perbankan Indonesia. Vol. 2, No. 2.

Suyono, E. 2017. Bebagai Model Pengukuran Earnings Management: Mana Yang Paling Akurat. SCA 7. Vol. 7, No.1.

Vonna, S., R. \& R., M., Daud. 2016. Analisis Perilaku Sticky Cost Pada Biaya Produksi dan Non-Produksi (Studi Empiris Pada Perusahaan manufaktur Yang Terdaftar di Bursa Efek Indonesia Periode 2011-2014). Jurnal Ilmiah MahasiswaEkonomi Akuntansi. Vol. 1, No. 1.

Weiss, D. 2009. Cost Behaviour and Analysts's Earning Forecast. The Accounting Review. Vol. 85, No. 4.

Windyastuti. 2013. Penetapan Target Terhadap Stickiness Cost. Jurnal Keuangan dan Perbankan. Vol. 17, No. 1.

Xue, S. \& Y., Hong. 2016. Earning Management, Corporate Governance and Expense Stickiness. China Journal of Accounting Research. Vol. 9.

Zhang, Y. 2016. The Stickiness of SG\&A Costs, Agency Problems and Competition Intensity. Disertasi dipublikasikan. Erasmus University Rotterdam. Belanda. 
